\title{
THE ROLE OF THE SISTER IN A RURAL HOSPITAL
}

\author{
J. V. Salayi
}

R.G.N., R.M., D.N.E., D.N.A.

Matron Grade I, Victoria Hospital, Lovedale

\author{
R. Mali
}

R.G.N., R.M., Dip. Comm. Health Nursing Sister, Victoria Hospital, Lovedale

G. N. Mali

R.G.N., R.M., Dip. Comm. Healıh Nursing Sister, Victoria Hospital, Lovedale.

\section{OPSOMMING}

In hierdie artikel word die werksomstandighede en eienskappe van 'n suster in 'n plattelandse hospitaal breedvoerig bespreek. Sy moet kennis dra van die kultuur van die gemeenskap wat sy dien asook al die beskikbare fasiliteite in en om die hospitaal. Met al hierdie inligting in ag geneem volg daar dan die doeltreffende behandeling van die pasiënt. Gesondheidsvoorligting en -opvoeding aan die personeel, pasiënt, sy familie en die gemeenskap speel eweneens ' $n$ belangrike role en stel die suster in staat om die mens as geheel te behandel.

\section{INTRODUCTION}

$\mathbf{N}$ urses sometimes seem to think that nursing in rural hospitals is less stimulating than that in city hospitals with all their super-sophisticated equipment and modern intensive care units: on the other hand, if we consider the concept of health which visualises a state of physical, mental and socio-economic wellbeing for the individual, his family and the community in which he lives and not merely the absence of disease, then we see nursing in rural hospitals as a great challenge for the nurse.

As in rural areas life is less busy than in cities, the number of patients in a hospital is usually manageable. Hence the nurse has the opportunity to treat her patients in their "totality" - physically, mentally and spiritually.

\section{COMMUNITY STUDY}

Seeing that the nurse is concerned with the total wellbeing of the patient, family and the community a detailed study will enable her to:

- observe the existing health problems and decide as to which problem should take priority

- give technical advice, with the major aim of prevention of disease and promotion of health

- refer people to other agencies, e.g. to social welfare.
Aspects to be Studied:

\section{Eating Habits}

The study of the eating habits of a community which are embedded in the culture of its people will help the nurse to establish the cause of the low nutritional state of the community. Her education of the community in respect of nutrition will not clash with the eating habits of the community.

\section{Health Services}

Knowledge thus obtained, may be utilised as follows:

- referring clients to the appropriate existing agency

- motivating for services to be commenced

- obtaining statistical data re prevalence of preventable disease in the community

- projects attempted before, and reasons for failure, to be investigated.

\section{Welfare Services}

Clients, such as geriatric or tuberculotic persons, may have to be referred for financial and social support.

\section{Recreational Facilities}

The utilisation of these facilities may be encouraged. Taking part in games helps to keep people physically fit and healthy and it aids the process of socialisation.

The sons of working parents are thus kept off the 
streets where they could get involved with gangs and they are protected from possible social deviations e.g. juvenile delinquency.

The following should also be considered:

- educational facilities

- religious facilities

- public health aspects e.g. water supply and sewerage disposal.

Collaboration with the authorities of various services is essential.

\section{ASPECTS OF THE SISTER'S ROLE \\ Patienı Care}

This includes all the aspects of preventive, curative, promotive and rehabilitative health care. Man must be helped to help himself, to develop his own potential, thus enabling him to make his own adaptations physically, emotionally and socially in society.

\section{Allocation of staff}

If done properly staff allocation leads to better patient care, economical and efficient utilisation of staff, better distribution of duties and personnel satisfaction.

\section{Nursing Care Plan}

The sister must, at all times, be informed of patients' condition, their treatment and progress, while worklists for all categories of staff should be written, clear and specific.

\section{Extended Role of the Sister}

As there is usually a shortage of doctors in a rural hospital, the sister must be able to diagnose a patient's disease/condition, and institute, in an emergency, treatment according to her knowledge and experience.

Continuous education is thus essential to enable her to stay abreast of advances in medicine and nursing.

\section{Supervision of Staff}

In-service training of all categories of staff.

\section{Co-ordinating Services and Maintainance of Good Relationships Co-ordinator}

The sister acts as co-ordinator between patient/doctor and family and here we wish to stress the importance of the family. To be able to combat health problems that beset any population group there must be provision of personalised, comprehensive family-centred health care because so many of these health problems arise in the family situation.

\section{Improvement of Doctor/Patient Relationship}

The sister can do much to improve the doctor/patient relationship. The patient must understand that his recovery from the ailment depends on a joint effort, that is, the doctor's and his own. If the cause of the disease has been explained to him, the course the disease will take and the treatment required, this relationship will be easy to establish. If he does not understand the cause of the disease and that the ailment will take a long time, he may refuse treatment and go home prematurely.

\section{Visitors}

The sister can allay the anxiety of visitors by the way she interviews them during visiting time and when she informs them of the patient's progress. In this way she prevents emotional trauma.

\section{The Care Team}

Good relationships within the care team, including paramedical and domestic staff, should be maintained.

\section{Education}

According to the present situation in the Republic of South Africa, Blacks are concentrated in rural areas or homelands where they lead a rural existence and are dependent upon an agricultural economy. Most patients are thus from a society still strongly influenced by its traditional beliefs and values. Malnutrition is prevalent for agricultural, economic and cultural reasons. To make matters worse, there is a high birthrate (as numerous children are the future support of their parents in old age!). There is also a high infant mortality rate and mortality and morbidity in general are due to infectious diseases, e.g. measles, whooping cough, tuberculosis etc.

All the above problems present a challenge to the sister. What a wonderful opportunity for her to be an educator, a teacher who cares! We all know that the secret of the care of the patient is in caring for the patient.

\section{Who are the people to be laught?}

Personnel - nursing - to enable them to render efficient and safe health care.

- domestic to provide a clean, comfortable and healthy environment.

\section{Patients and their Relatives}

(a) The young mother with frequent pregnancies and the husband's income inadequate

(b) Pregnant Women - who need to be taught

- the importance of the correct diet, even to the extent of breaking through cultural and traditional beliefs - for example, according to Xhosa custom a young woman is not suppose to eat eggs!

- the importance of attending antenatal clinics

- the importance of hygienic care of baby feeds and bottles

- the importance of child health - immunisa-, tion programmes

(c) The diabetic patient and his family - re diet, medicine and foot care

(d) The family of a previously mentally disturbed patient

(e) Patients and relatives re notifiable diseases - the importance of prevention - availability of all 
other health services in and around the community.

As the sister plays her role as a teacher, she must remember that each of her patients is a member of a family - large or small - and a member of a culture with complete traditional, social structure and religious beliefs. A special kind of relationship must be created between herself and her patients to enable her to achieve her goal.

\section{The Public}

The sister in a rural area has to accept the responsibility of sharing her knowledge with the wider public. Her education aims at changing the health attitudes of the people and equipping them with the knowledge that they will need to solve their own health problems.

Prevention of and early detection of disease are essential. The earlier sickness is detected, the less expensive treatment tends to be. Hospitals are sometimes burdened with those who are sick because they have not taken care that would protect them against illness. To point out a few examples:

(a) a woman who loses all her children at the age of $2 \frac{1}{2}$ years because of malnutrition, will be given education about what she should use to feed the children, why, how to prepare and when to give

(b) proper nutrition can prevent many subsequent diseases: of the bones, of the heart, of the liver, and so on

(c) fluoridation of water can cut down future expensive dental extractions.

Where can it be done? At the following:

Antenatal, child health, pre-school and school clinics: at places of employment, recreation clubs, geriatric clinics: at churches and community associations.

\section{Which methods can be used?}

These include talks and demonstrations at the abovementioned centres. The information be highlighted by poster and pamphlets, while public communication media could also be used e.g. magazines, radio and the local newspaper.

\section{Aspects to be borne in mind when preparing for Health Education}

The suster must be $-\mathrm{t}$ a $\mathrm{c} \mathrm{t} f \mathrm{u} l$

- have sufficient knowledge of the subject to be taught - know the language and cultural habits of the people to be taught - arrange a venue and time that will suit the people to be educated.

\section{CONCLUSION}

Nursing in rural hospitals is a challenge to the nurse. We believe that the rural nurse has a wonderful opportunity to care for and educate her people - she is less overloaded with work than are her counterparts in a city hospital.

A healthy atmosphere will result in a healthy relationship. What comes from the art goes to the heart! We must speak to one another only through a truly human language. Patients want to perceive a nurse as knowiedgeable, trustworthy, dependable, consistent and a real person - thus she will fulfil her role worthily in bringing health services to the people. 